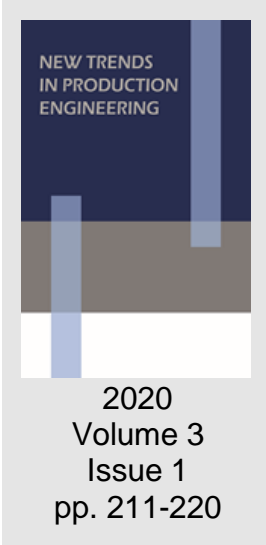

\title{
The Cutting Resistance of Rock Salt in Function of Temperature
}

\author{
Krzysztof Kotwica, Grzegorz Stopka \\ AGH University of Science and Technology, Poland
}

Volume 3

p. $211-220$

Date of submission to the Editor: 02/2020

Date of acceptance by the Editor: 03/2020

\section{INTRODUCTION}

Underground rock salt mining currently accounts for about a sixth of the global production of this resource. Depending on the form of deposition, geological and mining conditions and sediment purity, salt deposits can be exploited in several ways (Andrusikiewicz 2008, Poborska-Młynarska 2015), using both blasting and mechanical techniques. Salt rocks usually exhibit poor or average strength, depending on mineralogical and petrographic properties. In addition, their elastic-plastic behaviour in terms of strain-stress characteristics is not a typical rock behaviour, causing continuous strains as a function of time (Kolano \& Flisiak 2013, Phatthaisong et al. 2018, Yintong et al. 2012).

During salt rock excavation using mechanical methods, the cutting tools come into contact with the rock mass, producing friction and, consequently, an increase in temperature (Powell, 1969). In many cases the rock salt deposits lie at great depths, where the temperature of the surrounding rocks sometimes reaches or even exceeds $50^{\circ} \mathrm{C}$. Hence, before solid salt rock can be excavate by milling, the rock's cuttability and strength must be investigated, including at increased temperatures (Andrusikiewicz 2008, Yetkin et al. 2016, Raghavan \& Murthy 2018, Małkowski \& Kotwica 2019).

In the literature can be find information on mechanical alterations in salt due to changes in temperature. For example, it was reported that compressive strength at temperatures up to $200^{\circ} \mathrm{C}$ increases logarithmically (Ostadhassan \& Tamimi 2014). For the same temperature value was demonstrated that a considerable increase in temperature caused a linear decline in both the compressive and tensile strength of salt rock mass (Sriapai et al. 2012). In the same conditions the elasticity, expressed by the Young's modulus, might decline by half, whereas transverse strain, expressed by Poisson's ratio, usually increases by more than 10 percent (Iverson et al. 2012, Sartkaew \& Fuenkajorn 2013, Phatthaisong et al. 2018).

Since the rise in temperature of the rock mass due to friction by cutter heads is short-lived and localized, no such significant increases in temperature are 
recorded. During the tests, the results of which are presented in the article, the measurements of the cuttability index and the side chipping angle for three different temperature values - 20,50 and $80^{\circ} \mathrm{C}$ were carried out (Małkowski et al. 2019). Also, the same tests were performed after cooling of rock salt sample to room temperature. The tests were carried out on the special laboratory test stand. The selected mechanical parameters of rock salt - compressive, tensile and shear strength were also measured for the same temperature values and compared with results obtained in the first part of tests. The sample temperature measurements during the tests were also made using thermography camera. The tests were performed on the samples of Miocene salt from a Carpathian region. This salt is comparable to the salt deposed in the south region of Poland. The tested rock salt sample was not a pure salt sample. In the salt sample was included 99.7 percent halite. Other identified minerals included anhydrite and potassium and iron aluminosilicates - most likely clay minerals. It caused problems when collecting cylindrical samples from the salt block. When drilling with a Trepaner drill, these samples have cracked and split laterally into rings. This destroyed sample is shown in Figure 1. This caused that cubic and cuboid samples with a side of $50 \mathrm{~mm}$ at the base were cutted from the salt block.

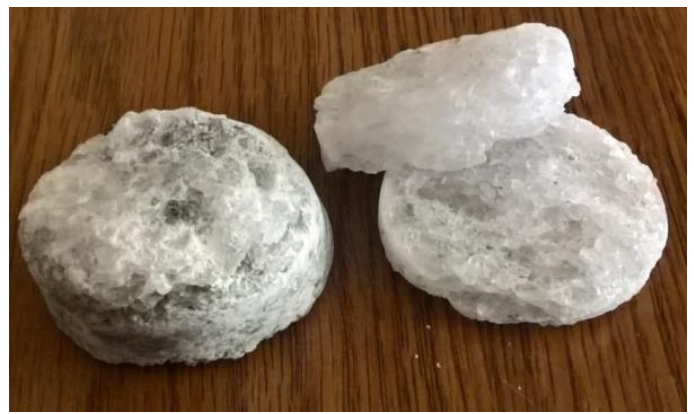

Fig. 1 View of destroyed sample after drilling using a Trepaner drill

\section{TESTS OF CUTTABILITY RESISTANCE}

The tests for determination of cutting resistance were carried out on the special laboratory test stand presented in Figure 2. This stand allows the recording value of forces components of the rock salt sample's cutting resistance.

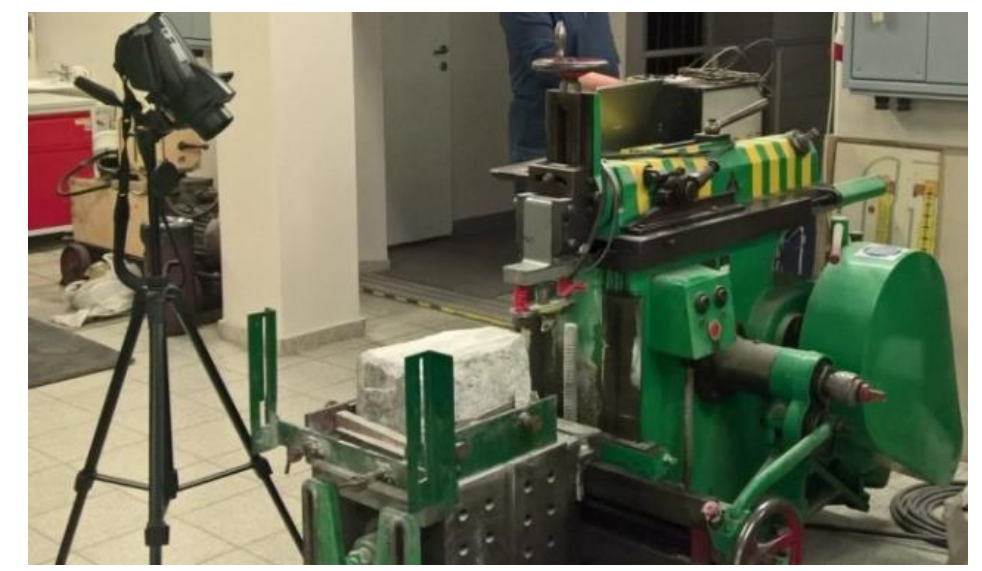

Fig. 2 View of special laboratory test stand for cutting resistance tests with a strain-gauge head 
The cutting resistance laboratory test stand consists of a horizontal shaper, a strain-gauge head (test cutter handle) fitted with a standard test radial pick, and a rock-sample specimen holder on the shaper table. The signals from the gauge head are sent through conductors via the strain-gauge amplifier to the measurement computer for recording and further processing and analysis (Małkowski et al. 2019).

The laboratory test to determine the cuttability index $A$ and the side chipping angle $\psi$ involved making open cuts in the rock samples using a standard test cutter. The cutting depth was predefined. The tests were designed to measure the components of the cutting resistance ( $\mathrm{Ps}$ - cutting force, $\mathrm{Pd}$ - pressure force, $\mathrm{Pb}$ - side force). The cuts after mining were measured to determine the actual cutting depth $\mathrm{g}_{\mathrm{s}}$ and cutting width $\mathrm{b}_{\mathrm{s}}$. The resulting values $\mathrm{Ps}, \mathrm{Pd}, \mathrm{Pb}$, $g_{s}$ and $b_{s}$ could then be used to determine the cuttability index $A$ (the ratio of the resultant cuttability resistance and the cutting depth) and the side chipping angle $\psi$ (the ratio of the opening-cut width difference arctangent and the double cutting depth).

The cutting tests were performed on the big dimension rock salt sample $\left(350 \times 200 \times 200 \mathrm{~mm}\right.$ ) for the temperatures of $22^{\circ} \mathrm{C}$ and about $50^{\circ} \mathrm{C}$ and $80^{\circ} \mathrm{C}$. The salt sample was heated into desired temperature in an oven. The sample temperature was controlled on the test stand directly before the measurement, after the sample's surface was even. The measurements were taken on cuts with a depth of $g_{s}=5 \mathrm{~mm}$ at the cutting speed $v_{s}$ of about $1 \mathrm{~m} / \mathrm{s}$. Each consecutive cut was made at a scale interval $t_{s}$ of at least $30 \mathrm{~mm}$. Also, thermographic images were captured during the cutting tests. The views of obtained cuts for cutting depth of $5 \mathrm{~mm}$, with temperature about $22^{\circ} \mathrm{C}$ and about $80^{\circ} \mathrm{C}$ are shown in Figure 3.

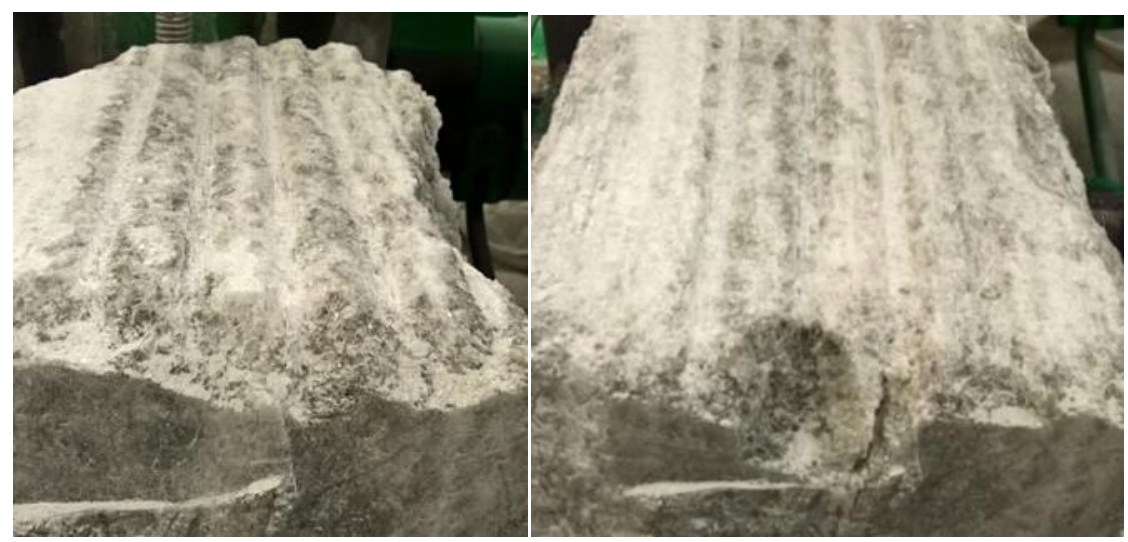

Fig. 3 View of obtained cuts for cutting depth of $5 \mathrm{~mm}$, with temperature about $22^{\circ} \mathrm{C}$ (left) and about $80^{\circ} \mathrm{C}$ (right)

The Figure 4 thermograms of the salt sample after cutting in three different temperatures are presented. The real temperature value was about $22.5^{\circ}, 55^{\circ}$ i $72^{\circ} \mathrm{C}$. On the thermographs can be observed that at $22^{\circ} \mathrm{C}$ the cut surface temperature rose to about $27.5^{\circ} \mathrm{C}$ along its entire length, at $55^{\circ} \mathrm{C}$, the 
temperature rose only in the end section of the cut - by $4^{\circ} \mathrm{C}$ and at $72^{\circ} \mathrm{C}$ the cut surface temperature rose up to $82^{\circ} \mathrm{C}$.

a)

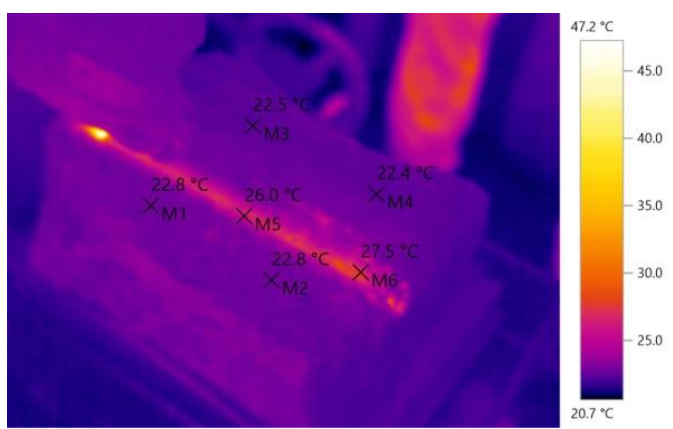

b)

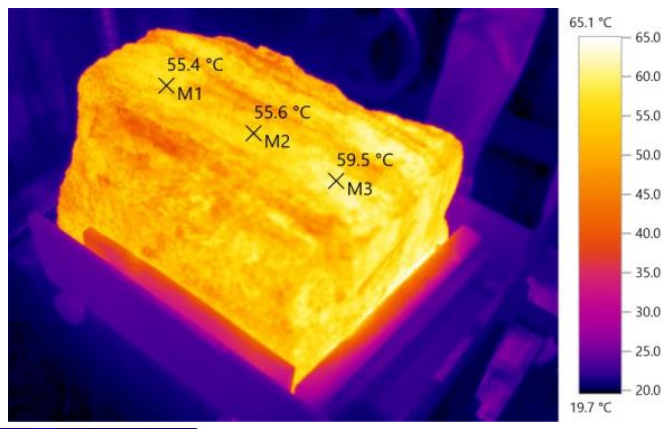

c)

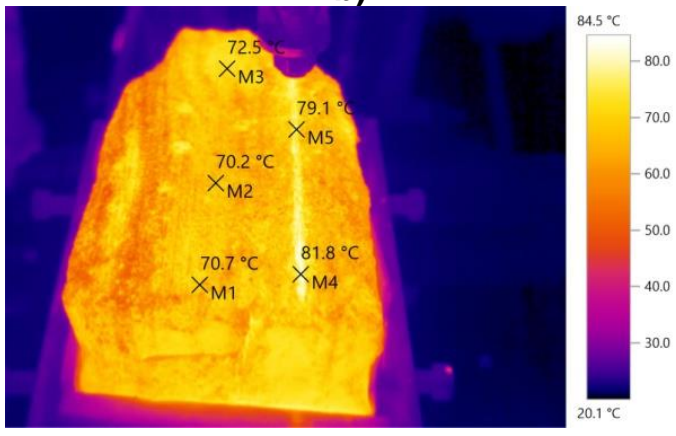

Fig. 4 Thermograms of a sample surface and performed cut during cutting with temperature: a) $22,5^{\circ} \mathrm{C}$, b) $57^{\circ} \mathrm{C}$ and c) $72^{\circ} \mathrm{C}$

After the salt sample has cooled to about $20^{\circ} \mathrm{C}$, a cutting test was carried out for a cut depth $g_{s}$ of approximately 5,7 and $10 \mathrm{~mm}$. The sample was cooled about 48 hours. The surface of the sample with these cuts (from the left in turn $\mathrm{g}_{\mathrm{s}} 5,10$ and $7 \mathrm{~mm}$ ) is shown in Figure 5. Further tests were not possible because on the sample crack along its entire height was observed, which caused the sample splitting into two parts.

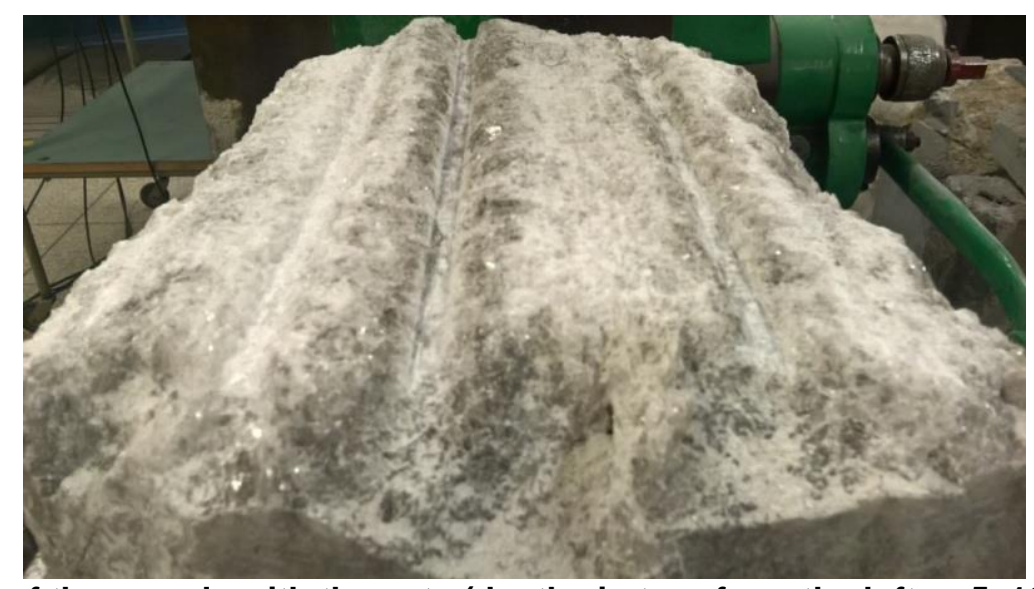

Fig. 5 View of the sample with the cuts (depths in turn from the left $g_{s} 5,10$ and $7 \mathrm{~mm}$ ) made at a temperature of about $20^{\circ} \mathrm{C}$, after cooling the sample

The graphs in Figure 6 show registered examples courses of $\mathrm{Ps}, \mathrm{Pd}$ and $\mathrm{Pb}$ force values for cuts with a depth of $5 \mathrm{~mm}$ at temperatures $22.5^{\circ}, 55^{\circ} \mathrm{i} 72^{\circ} \mathrm{C}$ and a cut with a depth of $10 \mathrm{~mm}$ for temperature $20^{\circ} \mathrm{C}$ after sample cooling. 

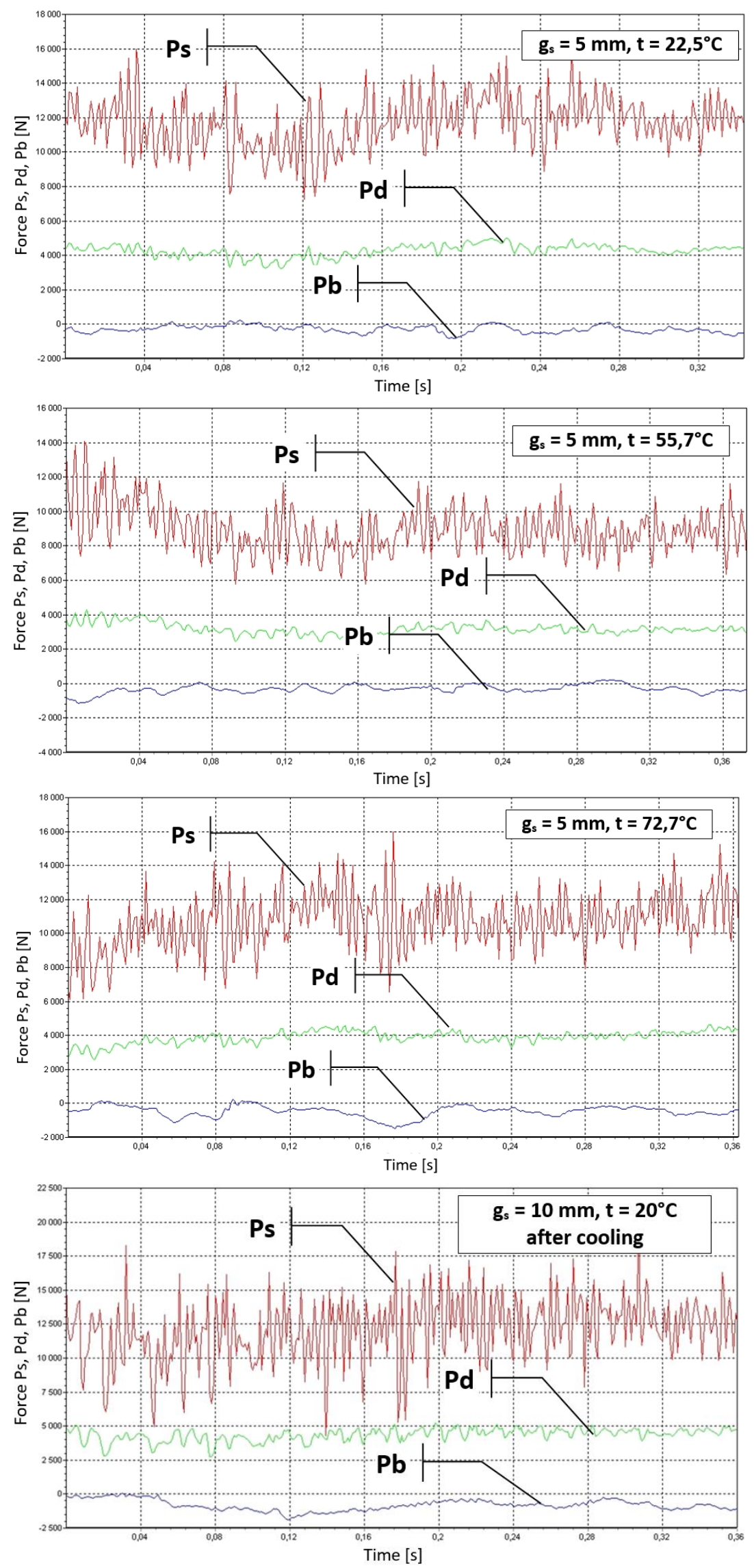

Fig. 6 The courses of $\mathrm{Ps}, \mathrm{Pd}$ and $\mathrm{Pb}$ force values for cuts with a depth of $5 \mathrm{~mm}$ at temperatures $22.5^{\circ}, 55^{\circ}$ and $72^{\circ} \mathrm{C}$ and a cut with a depth of $10 \mathrm{~mm}$ for temperature $20^{\circ} \mathrm{C}$ after sample cooling 
The charts show only sections during steady work, without starting and ending cutting. On Figure 7 the courses of Ps force value were compared for cutting depth $5 \mathrm{~mm}$ and three different sample temperature and for the same cutting depth after sample cooling. Based on recorded force courses and measurements of the obtained cuts the average values of cuttability index $A$ and the side chipping angle $\psi$ were estimated. These values are given below.

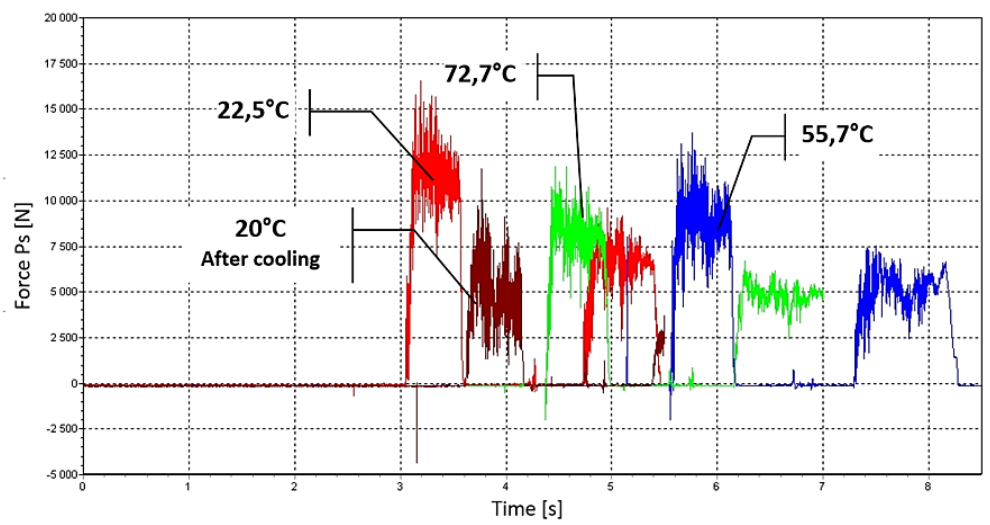

Fig. 7 Ps force value for cutting depth $5 \mathrm{~mm}$ for three different sample temperature and after sample cooling

The average value of cuttability index $A$ and the side chipping angle $\psi$ for three different sample temperature and cutting depth $\mathrm{g}_{\mathrm{s}}=5 \mathrm{~mm}$ :

- $22^{\circ} \mathrm{C}-\mathrm{A}=2192 \mathrm{kN} / \mathrm{cm}, \psi=55.8^{\circ}$,

- $55^{\circ} \mathrm{C}-\mathrm{A}=1742 \mathrm{kN} / \mathrm{cm}, \psi=51.2^{\circ}$,

- $72^{\circ} \mathrm{C}-\mathrm{A}=1653 \mathrm{kN} / \mathrm{cm}, \psi=48.7^{\circ}$.

The average value of cuttability index $\mathrm{A}$ and the side chipping angle $\psi$ for three different cutting depth after cooling the sample:

- $20^{\circ} \mathrm{C}\left(\mathrm{g}_{\mathrm{s}}=5 \mathrm{~mm}\right)-\mathrm{A}=917 \mathrm{kN} / \mathrm{cm}, \psi=48.7^{\circ}$,

- $20^{\circ} \mathrm{C}\left(\mathrm{g}_{\mathrm{s}}=7 \mathrm{~mm}\right)-\mathrm{A}=1497 \mathrm{kN} / \mathrm{cm}, \psi=51.2^{\circ}$,

- $20^{\circ} \mathrm{C}\left(\mathrm{gs}_{\mathrm{s}}=10 \mathrm{~mm}\right)-\mathrm{A}=1579 \mathrm{kN} / \mathrm{cm}, \psi=53.4^{\circ}$.

Taking into consideration the data on the workability degree of a given material depending on the on the cuttability index $\mathrm{A}$ and the side chipping angle $\psi$, based on the coal cuttability index presented in Table 1 (Biały W, 2005, Biały W, 2009, Biały W, 2011) it can be stated that at room temperature, the tested salt sample qualifies for medium workable materials.

Table 1 The degree of workability depending on the cuttability index A and the side chipping angle $\psi$

\begin{tabular}{|c|c|c|c|c|}
\hline $\begin{array}{c}\text { Cuttability index } \\
\mathbf{A}[\mathbf{k N} / \mathbf{c m}]\end{array}$ & \multicolumn{3}{|c|}{ Side chipping angle $\boldsymbol{\Psi}\left[^{\circ}\right]$} & $\begin{array}{c}\text { Degree } \\
\text { of workability }\end{array}$ \\
\cline { 2 - 5 } $\mathrm{A} \leq 1,8$ & $\mathrm{I}>70^{\circ}$ & $40^{\circ}<\Psi \leq 70^{\circ}$ & $\Psi \leq 40^{\circ}$ & easily workable \\
\hline $1,81<\mathrm{A} \leq 3,0$ & - & - & - & medium workable \\
\hline $\mathrm{A}>3,01$ & - & $\mathrm{II}$ & - & hard to workable \\
\hline & Brittle rock & Compact rock & Very compact rock & \\
\hline
\end{tabular}

After heating to $50^{\circ} \mathrm{C}$ it becomes an easily workable material, except that the value of the side chipping angle $\psi$ instead of increasing decreases. After 
overheating and cooling the salt sample, its cutting resistance clearly decreases. Compared to the values obtained at $20^{\circ} \mathrm{C}$, the cuttability index $\mathrm{A}$ decreases more than twice, with a side chipping angle $\psi$ comparable to measurements performed at $72^{\circ} \mathrm{C}$. On the other hand, the cuttability index $A$ values obtained for a cutting depth of 7 and $10 \mathrm{~mm}$ are about $10 \%$ lower than for measurements for $5 \mathrm{~mm}$ deep cuts made at $72^{\circ} \mathrm{C}$.

\section{TESTS OF SELECTED MECHANICAL PARAMETERS}

As was mentioned the additionally tests were carried out for determination of selected mechanical parameters - compressive $\sigma_{c}$, tensile $\sigma_{r}$ and shear strengths $\sigma_{\mathrm{s}}$. There tests were performed using cubic and cuboid samples with a side of $50 \mathrm{~mm}$ at the base (Małkowski et al. 2019). Four to eight determinations per parameter were made for each sample at pre-defined temperatures of 20 , 50 and $80^{\circ} \mathrm{C}$. Compressive strength $\sigma_{\mathrm{c}}$ was determined according to the PN-G 04303:1997 standard. The tensile strength $\sigma_{r}$ was determined using the transverse compression method (the so-called Brazilian test) according to the PN-G 04302:1997 standard. Shear strength $\sigma_{s}$ was tested using a method proposed by ISRM in 1975 involving an induced shear angle of $45^{\circ}$.

This involved compressing the sample in special moulds with one washer that adjusted the concentric alignment of the moulds to ensure equal shear area. View of the tested samples after the tests of compressive, tensile and shear strength is shown in Figure 8.
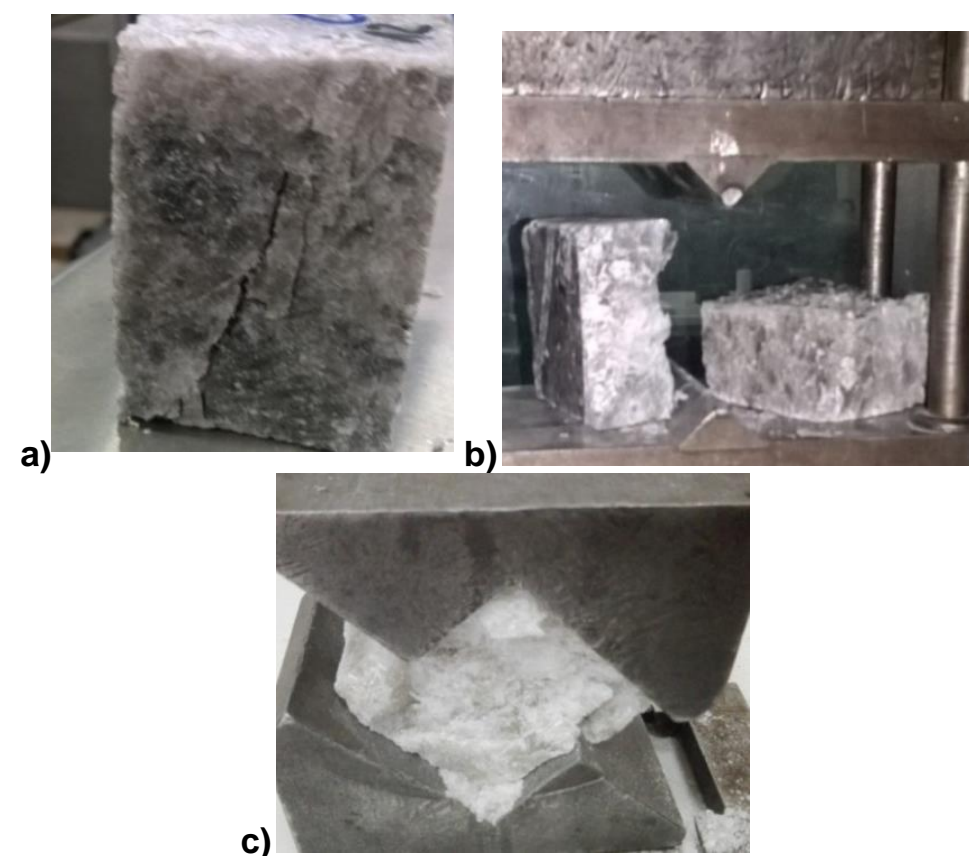

Fig. 8 View of tested samples after the tests of:

a) compressive strength, b) tensile strength and c) shear strength

During the tests, the outer temperature, as well as the inner temperature were being monitored continuously with a thermographic camera. Thermograms of the samples after compressive $\sigma_{c}$ and tensile strength $\sigma_{r}$ test $s$ performed in temperature $50^{\circ} \mathrm{C}$ are shown in Figure 9. It can be seen that the surface and 
inside temperature of the sample was comparable. The temperature drop was not greater than $1^{\circ} \mathrm{C}$ in 3-4 minutes.

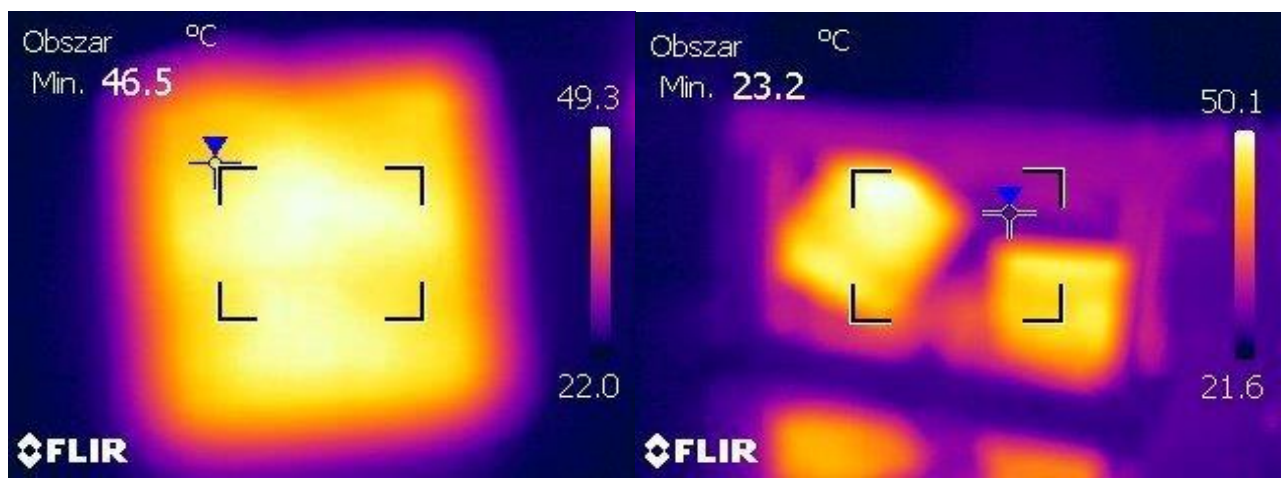

Fig. 9 Thermograms of the samples after compressive (left) and tensile strength (right) tests performed in temperature $50^{\circ} \mathrm{C}$

Table 2 summarizes the average test results. It is evident that both compressive $\sigma_{\mathrm{c}}$ and tensile strength $\sigma_{\mathrm{r}}$ values increased along with temperature, from 24.2 $\mathrm{MPa}$ to $28.4 \mathrm{MPa}$, and from 1.8 $\mathrm{MPa}$ to $2.1 \mathrm{MPa}$, respectively. A reverse trend was observed for shear strength $\sigma_{\mathrm{s}}$. As temperature increased, shear strength decreased from 22.1 MPa to 19.1 MPa. This can be considered an advantage especially for mechanical salt rock cutting. It should be noted, however, that the test methodology provided an induced shear angle of $45^{\circ}$, while the actual internal friction angle for salt is usually about $28-30^{\circ}$ (Kolano \& Flisiak 2013), although it can exceed $50^{\circ} \mathrm{C}$ as well (Ostadhassan \& Tamimi 2014).

Table 2 Values of shear strength $\sigma_{\mathrm{s}}$, compressive strength $\sigma_{\mathrm{c}}$ and tensile strength $\sigma_{r}$ in temperature function

\begin{tabular}{|l|c|c|c|c|c|c|c|c|c|}
\hline \multicolumn{1}{|c|}{ Parameter } & \multicolumn{3}{|c|}{$\begin{array}{c}\text { Shear } \\
\text { strength, } \boldsymbol{\sigma}_{\mathbf{s}}\end{array}$} & \multicolumn{3}{c|}{$\begin{array}{c}\text { Compressive } \\
\text { strength, } \boldsymbol{\sigma}_{\mathbf{c}}\end{array}$} & \multicolumn{3}{c|}{$\begin{array}{c}\text { Tensile } \\
\text { strength, } \boldsymbol{\sigma}_{\mathbf{r}}\end{array}$} \\
\hline Assumed temperature $\left[{ }^{\circ} \mathrm{C}\right]$ & 20 & 50 & 80 & 20 & 50 & 80 & 20 & 50 & 80 \\
\hline Parametervalue $[\mathrm{MPa}]$ & 22.12 & 21.04 & 19.07 & 24.17 & 25.18 & 28.44 & 1.81 & 1.92 & 2.06 \\
\hline $\begin{array}{l}\text { Final temperature } \\
\text { of the sample }\left[{ }^{\circ} \mathrm{C}\right]\end{array}$ & 23.16 & 48.76 & 71.81 & 23.05 & 50.26 & 79.17 & 23.08 & 49.69 & 75.91 \\
\hline
\end{tabular}

Table 3 also shows the average values of the ratio of compressive strength $\sigma_{c}$ to tensile strength $\sigma_{\mathrm{r}}$. The higher the value of this ratio, the easier workable is the rock. In the case of the tested salt sample, only a small increase in this ratio could be observed.

Table 3 Values of compressive strength $\sigma_{\mathrm{c}}$ to tensile strength $\sigma_{\mathrm{r}}$ ratio in temperature function

\begin{tabular}{|c|c|c|}
\hline \multicolumn{3}{|c|}{ Ratio $\boldsymbol{\sigma}_{\mathrm{d}} / \boldsymbol{\sigma}_{\mathrm{r}}$} \\
\hline $\mathbf{2 0} \mathbf{}^{\circ} \mathbf{C}$ & $\mathbf{5 0 ^ { \circ } \mathbf { C }}$ & $\mathbf{8 0}^{\circ} \mathbf{C}$ \\
\hline 13.35 & 13.12 & 13.81 \\
\hline
\end{tabular}




\section{SUMMARY AND CONCLUSION}

Analysis of the results obtained during tests allows to express the following conclusions.

The results of testing the mechanical parameters of the rock salt sample provided confirm that the salt is a springy-plastic rock material with characteristics that differ significantly from other rock centers.

The tested rock salt sample after heating was easier workable. In the rock salt sample heated to $80^{\circ} \mathrm{C}$, the cuttability index A decreased by almost $25 \%$, and the side chipping angle $\Psi$ by $13 \%$. The shear strength $\sigma_{\mathrm{s}}$ value decreased almost $14 \%$.

While compressive $\sigma_{c}$ and tensile strength $\sigma_{\mathrm{r}}$ of salt sample, when heated from room temperature to $80^{\circ} \mathrm{C}$ can increase by as much as $28 \%$. This is a considerable change in strength properties within a relatively small range of temperatures. So mechanical mining process by cutting can be compared to the mechanical parameter of shear strength $\sigma_{s}$. In all tests the increasing of temperature caused both the decrease of shear strength and cutting resistance value.

A very interesting observation is the fact that in the case of the rock salt sample heated to $80 \mathrm{C}$ and then cooled to room temperature there was a significant decrease of cutting resistance. In the case of cuttability index $A$, for the same cutting parameters its value decreased more than twice.

\section{REFERENCES}

Andrusikiewicz W. (2008). Możliwość zmiany sposobu urabiania soli kamiennej w KS Kłodawa. Gospodarka Surowcami Mineralnymi, vol. 24, no 3/2, pp. 173-183 (in Polish).

Biały W. „Empiryczne prognozowanie mocy ścianowych kombajnów bębnowych”. Wydawnictwo Politechniki Śląskiej. Seria: Górnictwo z. 262 Gliwice 2005. ISSN 0372-9508

Biały W. „Volba dobývacích kombajnů na základě výzkumů rozpojitelnosti uhlí“. VŠBTechnická univerzita Ostrava Fakulta strojní, Ostrava 2009. ISBN 978-80-2482032-3

Biały W. The selection of optimal method determining mechanical properties of coal layers. Systemy Zarządzania w Inżynierii Produkcji - Management Systems in Production Engineering 4/2011. ISSN 2083-5280

Iverson B. D., Broome S. T., Kruizenga A. M., Cordaro J. G. (2012). Thermal and mechanical properties of nitrate thermal storage salts in the solid-phase. Solar Energy, Vol. 86, pp. 2897-2911.

Kolano M., Flisiak D. (2013).Comparison of geo-mechanical properties of white rock salt and pink rock salt in Kłodawa salt diapir. Studia Geotechnica et Mechanica, Vol. XXXV, No. 1,DOI: 10.2478/sgem-2013-0010.

Kotwica K., Małkowski P. (2019). Methods of mechanical mining of compact-rock - a comparison of efficiency and energy consumption. Energies (electronical version) vol. 12 issue 18. no. 3562, pp. 1-25

Małkowski P., Bednarek Ł.,Kotwica K., Stopka G. (2019). The effect of temperature on the mechanical properties and workability of rock salt. New trends in production engineering: Monograph. Pt. 2, Social sciences. Warszawa Sciendo, pp. 28-37. 
Ostadhassan M., Tamimi N. (2014). Mechanical behavior of salt rock at elevated temperature. The $48^{\text {th }}$ US Rock Mechanics Conference, 1-4 June 2014, Minneapolis, USA, ARMA 14-7122.

Phatthaisong K., Sartkaew S., Fuenkajorn K. (2018). Effects of loading rate and temperature on strength and deformability of MahaSarakham salt. Songklanakarin J. Sci. Technol., vol 40, no 2, pp. 359-366.

Poborska-Młynarska K. (2015). Współczesne techniki eksploatacji soli kamiennej w kopalniach podziemnych. Przegląd Górniczy, no 12, pp. 140-146 (in Polish).

Powell F.(1969). Ignition of Gases and Vapors. Ind. Engr. Chem., Vol. 61, no. 12, pp. 29-37.

Raghavan V., Murthy Ch.S.N. (2018). Prediction of cuttability from rock cutting resistance. Journal of the Southern African Institute of Mining and Metallurgy. Vol. 118. No. (3). pp. 321-329.

Sartkaew S., Fuenkajorn K. (2013). Effects of stress rate on uniaxial compressive strength of rock salt under $0-100^{\circ} \mathrm{C}$. The $11^{\text {th }}$ International Conference on Mining, Materials and Petroleum Engineering. November 11-13 2013, Chiang Mai, Thailand, pp. 13-20.

Sriapai T., Walsri Ch., Fuenkajorn K. (2012). Effect of temperature on compressive and tensile strengths of salt. Science Asia, no 38, pp. 166-174.

Yetkin M.E., Hayati Y., Ferhan Ş., Bayram K. (2016). Examining the relation between rock mass cuttability index and rock drilling properties. Journal of African Earth Sciences. Vol. 124. pp. 151-158.

Yintong G., Haijun M., Chunhe Y. (2012). Mechanical properties of Jintan mine rock salt under complex stress paths. International Journal of Rock Mechanics and Mining Sciences, vol. 56, pp. 54-61

\begin{abstract}
.
Currently over then 16 percent of the total worldwide salt production is excavated in underground mines. Salt deposits often lie at great depths up to $1000 \mathrm{~m}$, where the temperature of the surrounding rocks reaches $50^{\circ} \mathrm{C}$ and even exceeds it. A large part of it is exploited using mechanical methods, mainly with the use of road headers and continuous miners. When excavating salt rock, the cutters of the road header mining head come into contact with the rock. This generate friction and in consequence a rise in temperature. In AGH University of Science and Technology the laboratory tests were carried out to determine the effect of temperature on cutting resistance and selected mechanical properties of rock salt. On the special laboratory test stand the rock salt sample was cutted at three different temperatures $-20,50$ and $80^{\circ} \mathrm{C}$. The cuttability index and the side chipping angle were measured for each temperature. Additionally the same tests were performed in the case of salt sample after cooling to room temperature. The selected mechanical parameters of rock salt - compressive, tensile and shear strength were also measured for the same temperature values. The obtained results were compared and described in the paper.
\end{abstract}

Keywords: Rock salt, cuttability index, workability, laboratory tests, temperature change of salt 